Agata Rozumko

The University of Bialystok

\title{
Lexicographic representations of English epistemic adverbs: an overview of problems based on selected monolingual and bilingual (English-Polish) dictionaries
}

\section{Introduction}

The term epistemic adverb refers to such adverbs as conceivably, obviously, possibly, presumably and unquestionably, i.e. adverbs used to express probability, possibility and certainty. The meanings and functions of such adverbs tend to be both language- and culture specific. As noted by numerous scholars, learning to speak with the appropriate degree of conviction is often a problem for non-native speakers of English (c.f. e.g. Holmes 1983). "They have to learn that the need to qualify one's statements and differentiate one's degree of "epistemic commitment" is greater in English than in most other languages" (Wierzbicka 2006: 251). Polish learners of English are no exception here. While both scholars and teachers pay quite a lot of attention to modal verbs, modal adverbs are considerably understudied and poorly described in the literature. The following analysis is an attempt to examine the extent to which commonly used dictionaries are helpful in explaining the meanings and uses of English epistemic adverbs. Dictionaries are the most immediate and the most accessible sources of information about foreign lexical items, therefore the quality of the descriptions they offer is very important. Both traditional and on-line dictionaries will be studied, with an attempt to outline the tendencies in the lexicographic description of epistemic adverbs.

\section{The scope of the study and the method}

The relative scarcity of publications concerning epistemic adverbs results from the fact that their cultural and linguistic significance has been noticed only rather recently. In 2006, Wierzbicka devoted a chapter of her book English: Meaning and Culture to an analysis of the role of epistemic adverbs in English. Her study provides important insights into cross-cultural and cross-linguistic differences in the use of epistemics and prepares the ground for further research. A number of significant problems connected with the description of epistemic adverbs, which in Polish linguistic tradition are usually referred to as modulators, modal particles or modal operators, have recently been raised by Danielewiczowa (2008a, 2008b, 2012), whose works offer important methodological suggestions in this area.

Wierzbicka (2006) argues that in comparison with other languages English possesses an extended class of epistemic adverbs, a property which she refers to as "a fact of great cultural significance" (2006: 249). She considers the frequent use of epistemic adverbs (and epistemic verbs) in English to be a consequence of the penetration of English speech patterns by the ideals of the Enlightenment. She writes: "[t]he cultural concerns reflected in the two [adverbs and verbs] categories are essentially the same, and in both cases they can be linked with the post-Lockean emphasis on the limitations of human knowledge, on the need to distinguish knowledge from judgement, and on differentiating between different degrees of assent" (Wierzbicka 2006: 247). It remains to be verified whether the class of epistemic adverbs is indeed so extended in modern English. However, even a brief study of the inventories of epistemic adverbs in English and Polish shows that the task of identifying equivalents within the two sets is not simple, e.g. Polish has no positive speech-act adverbs, such as arguably 
and admittedly (c.f. Rozumko 2012). Neither does it have equivalents of such adverbs as conceivably and reportedly: there are no adverbs derived from the Polish equivalents of conceive/conceivable and report. As a result, it is difficult for Polish learners to identify the contexts in which such adverbs should be used, and, as I have demonstrated elsewhere, their repertoire of English epistemic adverbs tends to be rather narrow (Rozumko 2008).

The dictionaries used in the present study include The Great English-Polish Dictionary by Stanisławski (1999), Collins English-Polish Dictionary (1996), The Longman Dictionary of Contemporary English (1990), and two online dictionaries: bab.la (http://pl.bab.la/slownik) and The Free Dictionary (www.thefreedictionary.com). They are all commonly used dictionaries which Polish learners of English are likely to consult. Bab.la was conceived as a dynamic project, open to contributions from its users, which is why its definitions are sometimes problematic. Its founders take no responsibility for the examples coming from external sources. Instead, they encourage the users of bab.la to suggest corrections and improvements. Despite these shortcomings, the dictionary is useful because it contains numerous examples illustrating the use of epistemic adverbs (and other lexical items) in different contexts. The English examples contain references to the sources from which they have been excerpted and links to the websites where they can be found in wider contexts. The Free Dictionary offers definitions which come from a number of traditional dictionaries, such as: The American Heritage Dictionary of the English Language (2009), Collins English Dictionary - Complete and Unabridged (2003), Collins Thesaurus of the English Language Complete and Unabridged (2009), as well as the electronic lexical database of English WordNet 3.0.

It is beyond the scope of the present paper to analyze the ways all English epistemic adverbs are defined in the dictionaries. Such a task would also require establishing their exact number in English because no satisfactory classification or selection criteria have been proposed for this category so far. Those singled out for the analysis include the adverbs which Wierzbicka (2006: 262) lists as the most central ones in English: allegedly, apparently, arguably, clearly, conceivably, evidently, obviously, possibly, presumably, probably, reportedly, seemingly, supposedly, undoubtedly and unquestionably, as well as two less frequent ones: avowedly and manifestly in order to examine the correlation between the frequencies of the adverbs and their treatment in the dictionaries. Whenever the frequencies of the adverbs are given, reference is made to their occurrences in the British National Corpus (100 million words).

\section{The omission of epistemic adverbs from dictionaries}

The most characteristic tendency in the lexicographic sources analyzed in the present study is that epistemic adverbs tend to be given less attention than other lexical means of expressing epistemic modality, i.e. the verbs and adjectives which they derive from. Some of the adverbs under analysis do not even have separate entries in the dictionaries. It is particularly characteristic of one of the biggest English-Polish (and Polish-English) dictionaries: Stanisławski (1999). Among its 200,000 entries there are no entries for: allegedly, arguably, evidently, manifestly, obviously, presumably, probably or reportedly. While their existence in English is ignored by the dictionary, the adjectives and verbs which they derive from: alleged, arguable, evident, obvious, probable, manifest, presume and report are all defined. Interestingly, Stanisławski defines the adverb presumedly, which is marginal in English in comparison with presumably. Presumedly is not evidenced in the British National Corpus, while presumably has 3,198 occurrences in it. The lexicographer clearly focused on the patterns of word formation rather than the function and frequency of the word in English: 
presumedly is likely to have been listed because of its morphological similarity to presumed, which precedes it in the dictionary. The hierarchy of Stanisławski's lexicographic description is clear: verbal meanings are given most attention, then nominal ones, followed by adjectival meanings. Adverbial meanings are clearly thought to be of secondary importance or even omissible. Sometimes, as in the case of the adverbs listed above, even their forms are not registered in the dictionary.

Collins English-Polish Dictionary (1996) is smaller in size than Stanisławski (1999) - it has 80,000 entries - but it lists all the adverbs from Wierzbicka's (2006) list; it does not include the less frequent avowedly and manifestly. Contrary to Stanisławski, it does not list presumedly, which suggests that, at least in the case of epistemic adverbs, its compilers were to a greater extent guided by the frequency of the adverbs in English. Stanisławski's dictionary is much older than suggested by the year of the publication of the edition analyzed in this study, and as such it belongs to an older lexicographic tradition than Collins. It was written in the years 1955-1964, and revised in the 1970s. It contains numerous specialist terms (botanical, zoological), at the same time omitting many everyday words, such as the epistemic adverbs mentioned above. Collins is less specialist in its choice of terminology and more comprehensive in its coverage of the general lexicon.

The monolingual Longman Dictionary of Contemporary English (1990) does not define avowedly, conceivably or manifestly. It does not have separate entries for allegedly, arguably, undoubtedly or unquestionably, though these adverbs are defined briefly in the entries for the adjectives or verbs which they are derived from. A short definition of allegedly is included in the entry for allege; arguably is defined briefly in the entry for arguable; undoubtedly is included in the entry for undoubted, and a definition of unquestionably can be found in the entry for unquestionable. In Longman, the focus is clearly on the most frequent ones, such as probably (26,552 occurrences in the British National Corpus) and obviously (10,658 occurrences). The less frequent adverbs, i.e. avowedly (37 occurrences), manifestly (199), conceivably (266), and unquestionably (219) are given less or no attention.

Online dictionaries are more comprehensive. The online English-Polish dictionary bab.la defines all the adverbs under analysis with the exception of conceivably. The monolingual Free Dictionary lists and defines all of them.

\section{The use of synonyms and multiple equivalents to explain the meanings of epistemic adverbs}

One of the most significant problems connected with the description of epistemic adverbs is that lexicographers tend to define them by providing their synonyms, i.e. they give other epistemic adverbs as their equivalents. This problem has already been noted by Danielewiczowa (2008b) with reference to monolingual dictionaries of Polish. In this way, individual properties of each of the adverbs are ignored and, as a result, none of them is properly defined. In the case of bilingual dictionaries, such treatment is to be expected because their users usually look for equivalents of English words in their native language. The problem is, however, that dictionaries often provide several Polish equivalents of each of the English epistemic adverbs, thus losing the specific qualities of both the defined item and each of the equivalents. Stanisławski usually gives three or even four Polish counterparts for each of the English epistemic adverbs under analysis:

apparently: (1) widocznie, najwidoczniej, najwyraźniej, (2) pozornie, na pozór

avowedly-jawnie, otwarcie 
clearly-oczywiście, najoczywiściej, najwyraźniej, bezspornie

conceivably - możliwie, it may conceivably have been so - to jest do pomyślenia, nie jest wykluczone

possibly - możliwie, być może

seemingly-pozornie, na pozór, widocznie

undoubtedly - niewatpliwie, z pewnościa, zapewne

supposedly - przypuszczalnie, podobno, rzekomo

unquestionably - niewątpliwie, z pewnościa, niechybnie, bezsprzecznie.

Such treatment suggests that either all the Polish equivalents have the same meanings and functions as their English counterparts or that none of them is in fact a direct equivalent of the English adverb. When four or five words, each having its own meanings and uses, are given as equivalents of one English adverb it is particularly difficult to identify the characteristic properties of the defined adverb. For example, the inclusion of bezspornie as one of the equivalents of clearly - alongside oczywiście, najoczywiściej, and najwyraźniejobscures rather than clarifies the meaning of the English adverb. Bezspornie is semantically and morphologically close to unquestionably or indisputably. It derives from the verb spierać sie (Eng. 'dispute, argue') in the same way as indisputably derives from the verb dispute. Neither of them refers to a statement based on available evidence the way clearly (and najoczywiściej and najwyraźniej) does.

Moreover, when one Polish adverb appears as an equivalent of several English adverbs the implication seems to be that those English adverbs also mean the same, e.g. niewatpliwie is given as an equivalent of both undoubtedly and unquestionably, and możliwie is given as an equivalent of conceivably and possibly. The choice of mozliwie as an equivalent of the two adverbs is also problematic since, despite its morphological form, which suggests a similarity in meaning to the adjective moziliwy ('possible'), the relation between the two is rather different and less straightforward than in the case of the English possible and possibly. Unlike possibly, możliwie is typically used before adverbs, as in możliwie daleko (roughly: 'as far as possible'). It can also be used to mean 'not too bad', e.g. when used in response to Jak sie czujesz? ('How are you feeling?'). It seems that Stanisławski was misguided by its morphological likeness to the adjective it derives from.

COLLINS dictionary (1993) does not use możliwie to define any of the epistemic adverbs under analysis. The Polish equivalents which it provides are:

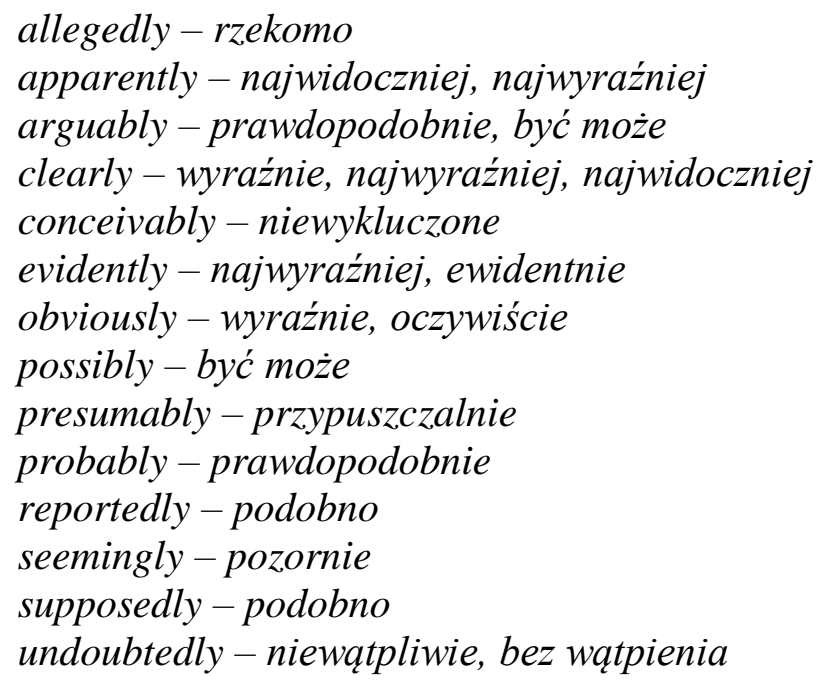


unquestionably - niewatpliwie, bezsprzecznie.

As in Stanisławski's dictionary, the same adverb is given as an equivalent of several English adverbs, which suggests an identity of meanings between such adverbs as arguably and probably; arguably and possibly; supposedly and reportedly; undoubtedly and unquestionably; apparently, clearly and evidently; clearly and obviously. A close inspection of all the Polish equivalents suggests that their provision is not very consistent, i.e. if być moze is given as an equivalent of both arguably and possibly, there seems to be no specific reason why prawdopodobnie is given as another equivalent of arguably but not possibly. The choice of some equivalents in both Stanisławski and Collins suggests that many epistemic adverbs are too readily treated as synonyms. Their individual semantic and syntactic properties are often ignored.

While defining English epistemic adverbs by providing lists of their rough equivalents in Polish does give dictionary users an idea of what their meanings are, such definitions are in fact imprecise. It is particularly true of those adverbs which have no direct counterparts in Polish, such as arguably, avowedly, conceivably and reportedly. In Polish there are no adverbs derived from the adjectives dyskusyjny (arguable) or wyobrażalny (conceivable). Likewise, there is no adverb corresponding in its morphological form to reportedly. The verb report itself has no straightforward equivalent in Polish. It may be translated as donosić, zgłaszać, or relacjonować (Collins), but none of these equivalents have any adverbial derivatives. Suggesting a semantic and syntactic identity between reportedly and supposedly, or arguably and possibly may therefore be rather confusing (and disappointing) for inquisitive readers.

The examples of their use are not very informative, either, e.g. in the entry for reportedly (Collins) we read: "he reportedly ordered them to ....". The example is so nonspecific that it could also be used in the entries for probably, clearly or obviously. The sentence illustrating the use of conceivably in the Collins dictionary is equally uncharacteristic: "he may conceivably be right". The dictionary leaves it to its readers to wonder if the sentence would mean anything else if conceivably was replaced with possibly or supposedly in this context. The entry for arguably (Collins) is even less precise: the Polish equivalents prawdopodobnie and być może are followed by the phrase "it is arguably ...." translated as "jest to, być może...".

The strategy of treating numerous epistemic adverbs as synonyms is well illustrated in the entry for presumably provided by bab.la, which gives the word prawdopodobnie as its Polish equivalent, while in the Polish translations of the twelve English sentences illustrating its use, it is most often rendered as przypuszczalnie, as in the following example:

Eng.: "It produces these strings of light, presumably as some form of defense."

Pol.: "Produkuje te strumienie światła, przypuszczalnie jako coś na kształt ochrony."

As already mentioned, bab.la is open to contributions from its users, which the founders of the project do not verify. This is why the dictionary is often unreliable, in particular in the case of epistemic adverbs, whose individual semantic properties are even overseen by trained lexicographers. For example, the entry for possibly gives the words może and możliwie as its Polish equivalents, and the words feasibly, perhaps, maybe, perchance, and mayhap as its synonyms in English. With możliwie, bab.la falls into the same trap as Stanisławski, but it goes even further and provides an incorrect sentence illustrating its use in Polish. One of its English examples of the use of possibly is: 
"The British government - any government is potentially the worst client in the world you could ever possibly want to have."

It is translated into Polish as:

"Brytyjski rząd - jakikolwiek rząd jest potencjalnie najgorszym klientem na świecie, którego *możliwie chcielibyście mieć."

The use of możliwie in this context makes the sentence awkward. In fact, in Polish there are no modal adverbs which could be used in this sentence with the same function as possibly.

Another example of poor translation from the bab.la dictionary is the rendition of a sentence illustrating the meaning of obviously. The English sentence is:

“And I'm not very good at this, so I guess I'd better go play video games or get into sports, or something like that, because I obviously don't belong here."

Its Polish version is:

"Nie jestem dobry w tym, więc lepiej będzie jak zagram w gry, zaangażuję się w sport, bo oczywiście tutaj nie pasuje”"

The choice of oczywiście as an equivalent of obviously is rather unfortunate; najwyraźniej would be a better option. Other collocations are also problematic: "zaangażuję się w sport" should be replaced with "zajmę się sportem", "zagram w gry" with "pogram w gry wideo" or "zagram w jakąś grę".

An important advantage of the bab.la dictionary is the provision of a considerable number of examples from English sources, which enables its Polish users to see the contexts in which certain lexical items are used. However, the Polish equivalents and translations it provides should be treated with caution.

The definitions provided by monolingual dictionaries are generally more informative, but they also rely on references to other epistemic adverbs in their definitions. The Free Dictionary defines (after Collins English Dictionary) allegedly as: reportedly, supposedly; evidently as obviously, clearly; probably as: most likely, presumably; undoubtedly as: certainly, definitely, unquestionably, etc.

Longman adopts the same strategy, defining clearly as: undoubtedly, plainly and using probably to explain the meaning of presumably: "it may reasonably be supposed that: probably: if you've already eaten, you presumably won't want dinner. Presumably you've read this notice (= I suppose/hope that you have)". Likewise, when defining probably Longman contrasts its meaning with that of certainly: probably: "almost (but not quite) certainly", and equates the meaning of undoubtedly (barely mentioned in the entries for undoubted, and doubt) with that of certainly: "There will undoubtedly (=certainly) be trouble with the unions if she is dismissed".

What usually distinguishes monolingual dictionaries from bilingual ones is the inclusion of notes on the usage of the lexical items which they explain. Bilingual dictionaries tend to be rather brief in this respect. However, in the case of the epistemic adverbs under analysis the notes offered by the monolingual dictionaries are also rather sparse. When defining possibly Longman refers the reader to its Language Notes on requests and tentativeness, which illustrate the use of possibly in polite requests and suggestions. The Free Dictionary has notes on the usage of arguably, saying that although the assertion it refers to is open to debate, it can be supported by persuasive argument, and allegedly - commenting on a recent tendency to use it in controversial, defamatory and sceptical statements. The entries for the other epistemic adverbs under analysis do not contain any notes on their usage. 


\section{References to the entries of adverbs of a similar type}

It is also common practice for dictionaries to invite their readers to compare adverbs of a similar type. Among the adverbs discussed here there is a group of adverbs referred to as evidential, i.e. those which signal that the speaker's claim is based on some evidence (cf. Simon-Vandenbergen and Aijmer 2007). They include apparently, clearly, obviously, evidently and manifestly. When defining each of them, Longman refers the readers to the entries of the others in the group:

"apparently: it seems (that); according to what I have heard: I wasn't there, but apparently it was a good party. /Apparently they're intending to put up the price of electricity. /Did she pass her test? Apparently not. (2) it is clear (that): Apparently she never got my letter after all. - compare EVIDENTLY, OBVIOUSLY"

"evidently: it is proved by clear signs (that); it is plain (that): He's evidently not well. compare APPARENTLY, OBVIOUSLY"

"obviously: it can be easily seen (that); plainly: This key is obviously the wrong one./Is she sorry? -Obviously not! Look at her. - compare APPARENTLY, EVIDENTLY"

Such systemic treatment has its advantages because it presents the adverbs in a broader perspective and makes the readers aware of the existence of certain categories within the class of epistemic adverbs. Instead of looking at each of them individually and offering more or less accurate equivalents, it presents them as a system of interrelated elements with their individual properties and differences. However, for such a presentation to work it must follow certain principles. First of all, all the elements of the system should be presented, and, secondly, the differences between them should be stated explicitly, explained clearly, and illustrated with examples.

Most of the Longman definitions of the adverbs which can be classified as evidential state that they rely on some sort of evidence. However, they do not specify whether the evidence is of the same or a different kind for all of them. Thus, based on Longman, apparently seems to refer to aural evidence ("according to what I have heard"), while the definition of obviously suggests a reliance on visual evidence ("it can be seen"). The reference to obviously in the definition of plainly suggests that it also refers to visual evidence. The same, by extension, may be postulated for clearly, which is defined by a reference to plainly. In the case of evidently the type of evidence ("clear signs") is not specified. Manifestly, as already mentioned, is not listed in the Longman dictionary.

However, an inspection of the quotations included in the British National Corpus shows that the above interpretation is not necessarily correct. Among the 7,582 occurrences of apparently in the BNC there are numerous sentences which demonstrate that the conclusion that the adverb relies on aural evidence is wrong, e.g.:

"Later in the letter, considering apparently a different sort of poem written by Williams, Hart Crane confesses."

"For four days the battalion suffered continuous attacks from apparently limitless numbers, during which it made a fighting withdrawal of 10 miles."

"There we discovered the $£ 7.50$ hamburger meal, flower-selling girls with Chanel handbags and wealthy exhibitionists who apparently enjoyed being part of a human zoo, preening themselves on their extravagant yachts while the hoi-polloi stared up from the quayside." 
It thus appears that interpreting Longman definitions literally, and assuming that they focus on the most distinctive properties of the lexical items which they explain is likely to lead to wrong conclusions. The strategy of comparing the meanings of adverbs of the same kind only makes sense when some differences between them are pointed out. Otherwise, the comparison only blurs their meaning. Longman entries for the other, i.e. non-evidential subcategories of the epistemic adverbs under analysis do not contain any references to the entries of adverbs of a similar type.

\section{Defining adverbs with reference to the corresponding adjectives and verbs}

Another tendency in the lexicographic descriptions of epistemic adverbs under analysis is explaining their meanings with reference to the verbs and adjectives they derive from. As noted by Danielewiczowa (2008), this approach is not restricted to dictionaries; it is also commonly used in grammar books and monographs on modality. The most extreme case of such a reduction of adverbial meanings involves putting adverbs at the end of the entries for the related adjectives and verbs, rather than explaining their meanings in separate entries. This is the case with the Longman definitions of allegedly - defined briefly in the entry for allege as "according to what is alleged", and unquestionably - defined in the entry for unquestionable as "which cannot be doubted, certain, indisputable". When epistemic adverbs are defined in separate entries their meanings are also often explained with reference to the adjectives or verbs which they derive from, as in the Longman definition of possibly: "in accordance with what is possible", the Free Dictionary definitions of allegedly: "it is alleged that", arguably: "it can be argued that", clearly: "in a clear manner", presumably: "one presumes or supposes that", and obviously: "it is obvious that". The verbal and adjectival meanings are clearly perceived as central while the explanations of adverbial meanings are reduced to the minimum. Such treatment ignores both the specific characteristics of epistemic adverbs as a category and the individual properties of each of the adverbs within the group.

As stressed by both Wierzbicka (2006) and Danielewiczowa (2008, 2012), epistemic verbs, adjectives and adverbs have their distinct meanings and functions. In expressing the speaker's knowledge, verbs are more subjective and speaker-centred than adverbs and adjectives. Phrases such as I presume, I argue, and I suppose emphasize the speaker's stance and his/her point of view. Adverbs, on the other hand, "objectify the speaker's own attitude by extending it, in anticipation, to other people" (Wierzbicka 2006: 289). By using an epistemic adverb the speaker indicates that s/he thinks "that his or her own stand can be shared by other people" (Wierzbicka 2006: 287). Epistemic adjectives, in turn, lack the element of subjectivity in their meaning. Expressions such as it is possible, or it is obvious make a statement sound more objective. Thus, as Danielewiczowa (2008a: 50-51) puts it, when the meanings of epistemic adverbs are reduced to the meanings of epistemic verbs, the element of objectivity is lost, while, by reducing their meanings to the meanings of adjectives we lose the element of subjectivity which is also inherent in their meanings.

\section{Conclusions}

As demonstrated above, dictionaries tend to pay less attention to epistemic adverbs than epistemic verbs and adjectives. Adverbs are more commonly omitted from dictionaries, in particular those whose frequency in English is not very high, such as manifestly and conceivably. Adverbial meanings are treated as secondary and derivable from adjectives and verbs, much in the same way as adverbs are derived from adjectives and verbs morphologically. This is why adverbs are often included in the entries of adjectives and verbs. 
The individual properties of each of the epistemic adverbs are not given much attention. Those which express similar meanings tend to be treated as synonyms, which is why monolingual dictionaries use lists of synonyms to define them, and bilingual dictionaries provide a number of Polish equivalents of each English adverb. From the perspective of a dictionary user the dictionaries would be more useful if they presented epistemic adverbs as a system of interrelated elements with their individual properties. However, such a presentation will only be possible when epistemic adverbs receive a more systematic treatment from language scholars.

\section{References:}

Danielewiczowa, Magdalena. 2008a. "Opis przysłówków epistemicznych jako wyzwanie teoretyczne", Prace Filologiczne t. LIV. Seria Językoznawcza, 47-62.

--. 2008b. "Jak nie należy opisywać przysłówków epistemicznych?", Wiener Slawitischer Almanach, Sonerband 72, Lexikalishe Evidenzialitäts-Marker in slavischen Sprachen, 109128.

--. 2012. W głąb specjalizacji znaczeń. Przystówkowe metapredykaty atestacyjne. Warszawa: Uniwersytet Warszawski, Bel Studio.

Holmes, Janet. 1983. "Speaking English with the appropriate degree of conviction". In: C. Brumfit (ed.) Learning and Teaching Languages for Communication: Applied Linguistics Perspectives. London: Centre for Information on Language Teaching and Research, 100113.

Rozumko, Agata. 2008. "An interdisciplinary approach to teaching grammar to prospective teachers of English". In: K. Bogacki, B. Głowacka and D. Potocka (eds.) Interdisciplinary Perspectives in Foreign Language Teacher Education, Białystok: Wydawnictwo Uniwersytetu w Białymstoku, 309-318.

--. 2012, "Speech-act adverbs in English and Polish: a cross-linguistic and cross-cultural comparison", Białostockie Archiwum Językowe 12, 183-196

Simon-Vandenbergen, Anne Marie and Karin Aijmer. 2007. The Semantic Field of Modal Certainty: a Corpus-Based Study of English Adverbs, Berlin and New York: Mouton de Gruyter.

The British National Corpus: http://www.natcorp.ox.ac.uk/

Wierzbicka, Anna. 2006. English: Meaning and Culture. Oxford: Oxford University Press.

\section{Dictionaries:}

Collins English-Polish Dictionary. 1996. (ed. by J. Fisiak), Warszawa: Polska Oficyna Wydawnicza.

Longman Dictionary of Contemporary English (2 ${ }^{\text {nd }}$ edition) $1990 . \quad$ Longman: Harlow/Warszawa: PWN.

Stanisławski, Jan (1999), The Great English-Polish Dictionary, Warszawa: Wydawnictwo Philip Wilson.

http://pl.bab.la/slownik/

http://www.thefreedictionary.com 
